\title{
The Effect of Process Based Approach on Seventh Grade Students' Writing Achievement
}

\author{
Aditya Blangsinga ${ }^{1}$, Ni Nyoman Padmadewi ${ }^{2}$, Putu Adi Krisna Juniarta ${ }^{3}$ \\ ${ }^{123}$ English Education Department, Universitas Pendidikan Ganesha, Indonesia
}

Keywords:

Teaching Writing,

Process Based Approach,

Descriptive Paragraph

\section{ABSTRACT}

Abstract: This study aimed at investigating the implementation of the process based approach in teaching writing in order to know its effect to the improvement of students' writing achievement Furthermore, the quantitative method was used in this research with quasi experimental design. The subjects involved in this study were 35 Junior High School students from VII A7 class in SMP Negeri 1 Singaraja, Bali, Indonesia. The proficiency test such as pretest and post test were conducted in this study in oder to collect the data. The students were given a treatment for about eight weeks. The data obtained were analysed by using descriptive and inferential statistics. It was analyzed using SPSS. As the result of statistical analysis, it was found that sig 2-tailed result in the paired samples $t$-test wast 0.00 , which was below 0.05 . In terms of the mean score, it was found the mean score in the post test (80.46) was higher than the mean score in the pretest (68.59). So, it can be concluded that process based approach had a significant effect on the seventh' grade students writing achievement.

Correspondance address:

E-mail: wismakrisna@gmail.com (Aditya Blangsinga)

\section{Introduction}

Writing is a productive skill in the written mode which is more complicated and seems to be the hardest of the skill (Saputra \& Marzulina, 2015). Even for native speakers, communicate using written form is not an easy thing because it involves not just a graphic representation of speech, but the development and presentation of thoughts in a structured way as well.

Writing is preserved as a tool to express ideas in everyday lives such in business, creativity, and education. In education context, writing has been recognized as one of essential language skill that needs to be mastered by the learners. As Banat (2007) points out that writing skill is invaluable for helping students communicate and understand how the parts of language. It is also supported by Pasand and Haghi (2013) that say writing gives improvement of ideas, knowledge and experience in learning. Therefore, since writing helps learners in conveying ideas an concept, it is needed to implement writing in teaching language.

However, writing is particularly difficult especially in foreign language context. Lindsay (2000) notes that producing a coherent, fluent, and extended piece of writing is probably the most difficult thing to do in language regardless whether the language in question is a first, second or foreign. The difficulties of EFL students are often found in making a paragraph or a composition and deciding suitable grammar. Besides, in creating a piece of work, they tend to imitate, copy and transform teacher's supplied models rather than by constructing their own. 
Recently, writing is more than simply linear activity consisting of several stages that are independent and sequenced. It is recognized as a complex and integrated set of processes that are interactive and recursive. As Abu-Jaleel (2001) argue that writing is re-planning or backwards and forwards process between drafting and revising. In other words, it is acceptable if students made a mistake during writing. They can revise as much as they write until it rights.

Conventional theories concerning to writing mainly put emphasis on the result of the product (Sakoda, 2014). The accuracy of produced texts, focusing on areas such as correct grammar, spelling and usage are assessed at the end without any intervention in the writing process itself. Fathman and Whalley's (1990) reveal that students can improve grammatical accuracy when teachers underline grammatical errors in the students' texts. In the other words, teacher's correction motivates the students to be aware of grammatical structure.

This traditional approach on teaching writing is commonly found in Bali. Based on the preobservation on SMPN 1 Singaraja, it was found that the writing focus is usually on the product of the written text, rather than the process that students go through while writing. In addition, teacher is frequently found limit the time and the topic of the text. It made the students cannot explore their topic through text and tend to imitate the example given by the teacher.

By considering to this paradigm, an appropriate and innovative approach in teaching writing should be implemented in order to improve students' writing ability. One of approaches that can help teacher in teaching writing is process based approach. Process-Based Approach of English Writing teaching has been advocated in contrast with the conventional product-oriented method of teaching writing.

\section{Methods}

This research analyzed its impact to the students achievement. This study applied quantitative methods research as the research methodology. The quantitative data was obtained from the students' achievement based on the test on writing score. The population of this study was the seven grade students of SMP N 1 Singaraja in academic year of 2018/2019. The sampling technique that was used was cluster random sampling by using lottery. According to Fraenkel and Wallen (1993), cluster random sampling is used when the population members are grouped into units that can be conveniently used as cluster. Therefore, the sample was taken from VIIA7. There were 32 students in that class.

To collect the data, the instruments used in this research were lesson plan and essay writing test. All of the instruments were validated trough three process of instrument validation, namely construct validity, content validity, and reliability. Construct validity was done to get the readability and credibility of the instrument. Meanwhile, content validity was done to assure the relevance of the instrument. In addition, interater reliability was used to check the consistency of instruments through the expert's judgement.

Morerover, in analyzing the data, the researcher used descriptive statistics analysis and paired samples t-test in order to analyze the data quantitatively. In this case, the application which was used to process the data was IBM SPSS Statistics 20.

\section{Results and Discussion}

Essay writing test was used as the instruments for assessing students' score toward descriptive text. The test was conducted by the teacher to the class VII A7 students of SMPN 1 Singaraja. To know 
the impact, there were two test given in order to assess the students writing score. Those were pretest and post test. Therefore, the data of the studentst' achievement before and after teaching writing by using Process Based Approach can be seen in the following chart.

Chart 1. The Comparison between Students' Pretest and Post Test Result

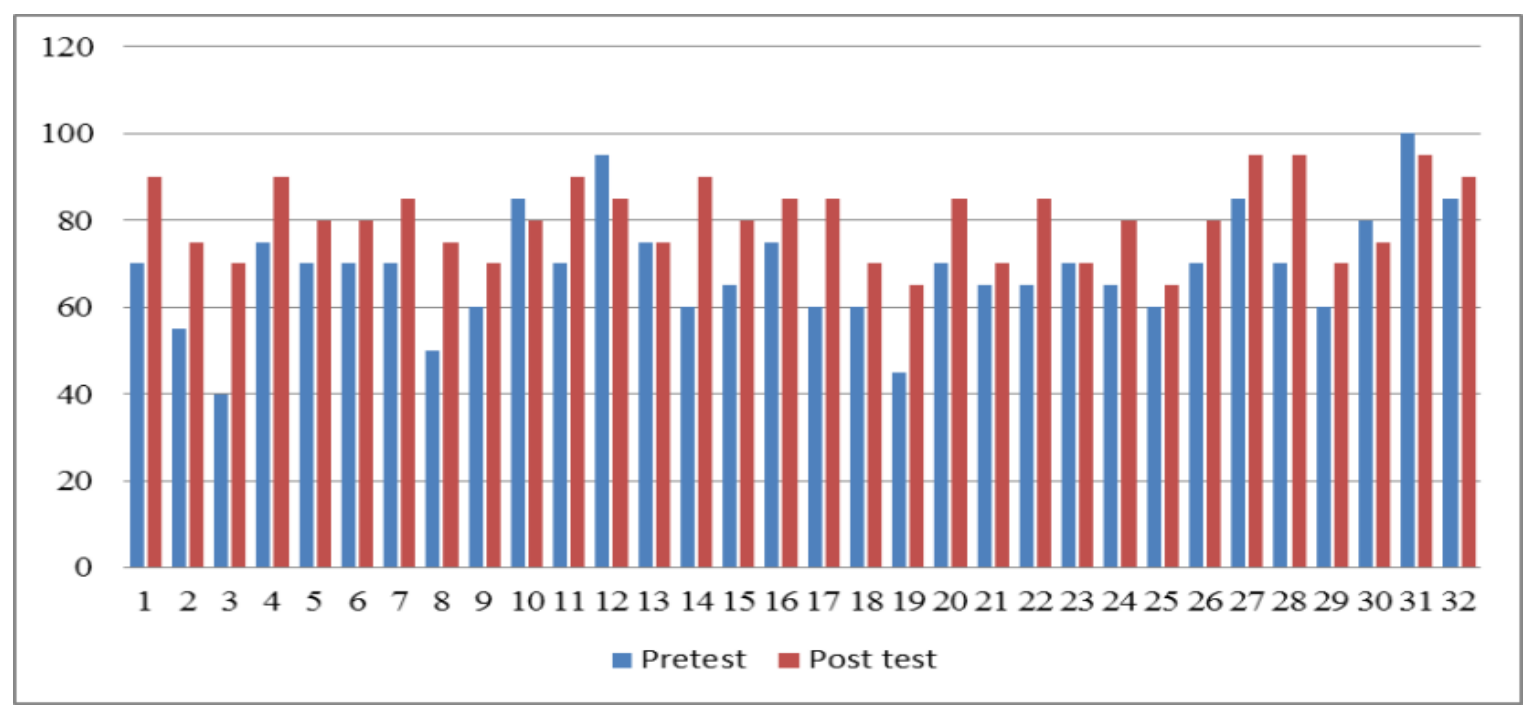

From the Chart 4.17 it can be shown the students' pretest and post test score. As can be seen on the table, there were two students significantly increased by 30 points (Student 3 and 14), three students increased 25 points (Student 8, 17 and 28), five students increased 20 points (Student 1, 2, 11, 19, 22), five students increased 15 points (Student 4, 7, 15, 20, 24), eight students increased 10 points (Students 5, 6, 9, 16, 18, 26, 27, 19), three students increased 5 points (Student 21, 25, and 32), two students did not increase or unchanged (Student 13 and 23), three students decreased 5 points (Students 30 and 31) and one student decreased 10 points (Student 12).

In addition, the students who got excelent score ( 285$)$ were increased in the post test. In the pretest, there were only five students got excellent (Student 10,12,27,31 and 32). Meanwhile in the post test, there were fourteen students who got excelent score (Student 1, 4, 7, 11, 12, 14 ,16, 17, 20, 22, 27, 28,31 , and 32). Students number 12, 27, 31, and 32 got excelent score in the pretest and posttest. The higher score in both pretest and postest was reached by students number 31 with the score 100 and 95 . On the other hand, students who got not really good score $(<70)$ was decreased. In the pretest, there were fourteen students who did not get a good score (Student 2, 3, 8, 9, 14, 15, 17, 18, 19, 21, 22, 24,25, 29). Meanwhile, there were only two students who not reach good scored (Student 19 and 25). Both of them also got not really good score in the pretest. Nonetheless, their score were increased. The lowest score both in the pretest and postest was gotten by student number 19 with 45 and 65 .

Furthermore, descriptive statistics analysis and inferential statistics analysis were used to measure the impact of the Process Based Approach to the students' writing test. Before analyzing the data, normality test was conducted to assess whether data were normally distributed or not. Furthermore, SPSS.16 One sampe Shapiro-Wilk test by the value of significance $(\alpha)=0.050$ was used in this study. The result of the normality test can be seen on the following table: 
Table 1. The Result of Normality Test

\begin{tabular}{|c|c|c|c|c|c|c|}
\hline & \multicolumn{3}{|c|}{ Kolmogorov-Smirnov $^{2}$} & \multicolumn{3}{|c|}{ Shapiro-Wilk } \\
\hline & Statistic & $\mathrm{df}$ & Sig. & Statistic & $d f$ & Sig. \\
\hline $\begin{array}{l}\text { PRE } \\
\text { TEST }\end{array}$ & 175 & 32 & ,014 & 961 & 32 & ,285 \\
\hline $\begin{array}{l}\text { POST } \\
\text { TEST }\end{array}$ & 132 & 32 & 170 & ,941 & 32 & ,078 \\
\hline
\end{tabular}

The standard significant of education is 0.05 ( $\alpha=5 \%$ ). To determine data is normal distribution or not it can be seen from the result of data normality testing. Based on the output from SPSS presented above known that the significance value from pretest was .285 and from the post test is .078 . Both value from pretest and post test are bigger than 0.05 . So, it can be interpreted that both of data (pretest and post test score) were in the normal distribution.

Table 2. The Result of Descriptive Statistics

\begin{tabular}{|l|r|r|r|r|r|}
\hline & \multicolumn{2}{|c|}{ PRE TEST } & \multicolumn{2}{c|}{ POST TEST } \\
\cline { 3 - 6 } & & Statistic & Std. Error & Statistic & Std. Error \\
\hline Mean & 68.5938 & 2.28108 & 80.4688 & 1.5773 \\
\hline 95\% Confidence & Lower Bound & 63.9414 & & 77.2518 & \\
\hline \multicolumn{2}{|c|}{ Upper Bound } & 73.2461 & & 83.6857 & \\
\hline 5\% Trimmed Mean & 68.4375 & & 80.5208 & \\
\hline Median & 70 & & 80 & \\
\hline Variance & 166.507 & & 79.612 & \\
\hline Std. Deviation & 12.90376 & & 8.92255 & \\
\hline Minimum & 40 & & 65 & \\
\hline Maximum & 100 & & 95 & \\
\hline Range & 60 & & 30 & \\
\hline Interquartile Range & 15 & & 17.5 & \\
\hline Skewness & & 0.248 & 0.414 & -0.041 & 0.414 \\
\hline Kurtosis & 0.731 & 0.809 & -1.042 & 0.809 \\
\hline
\end{tabular}

It can be shown by the table that the mean score of the post test was higher than the mean score of the pre test. It can be seen that the mean score for pretest was 68.59 menwhlie the mean score of the post test was 80.46. In addition, the median score of the pre test was 70.00 while the median score of post test was 80.00 . The range of pre test was 60 while the range of post test was 30 . The variance of the pre test was 166.50 and the variance in the post test was 79.612. Furthermore, the standrad deviation of the pretest was 12.90 while the standard deviation of the post test was 8.92 .

Furthermore, hypothesis testing was done in order to test whether or not there is any significant effect of Process Based Approach used by the teacher in teaching writing toward seventh grade students at SMPN 1 Singaraja. It was analyzed by using 2 tailed paired samples t-test SPSS application program. The result of the testing was displayed in the following table. 
Table 3. The Result of Paired Samples Test

\begin{tabular}{|c|c|c|c|c|c|c|c|c|c|}
\hline \multicolumn{10}{|c|}{ Paired Samples Test } \\
\hline & & \multicolumn{5}{|c|}{ Paired Differences } & \multirow[b]{3}{*}{$t$} & \multirow[b]{3}{*}{$d f$} & \multirow{3}{*}{$\begin{array}{l}\text { Sig. (2- } \\
\text { tailed) }\end{array}$} \\
\hline & & \multirow[b]{2}{*}{ Mean } & \multirow{2}{*}{$\begin{array}{c}\text { Std. } \\
\text { Deviation }\end{array}$} & \multirow[b]{2}{*}{ Std. Error Mean } & \multicolumn{2}{|c|}{ of the Difference } & & & \\
\hline & & & & & Lower & Upper & & & \\
\hline Pair 1 & $\begin{array}{l}\text { PRE TEST } \\
\text { - POST } \\
\text { TEST }\end{array}$ & -11.87500 & 10.37600 & 1.83423 & -15.61595 & -8.13405 & -6.474 & 31 & .000 \\
\hline
\end{tabular}

Regarding to the Table 3, a paired-samples t-test was conducted to evaluate the impact of the Process Based Approach (PBA) to the students' achievement on writing. There was a statistically significant increase in writing score scores from Pretest $(M=68.59, S D=12.90)$ to Postest $(M=80.46, S D$ $=8.29), \mathrm{t}(31)=6.47, \mathrm{p}<.0005$ (two-tailed). The mean increase in PBA scores was 11.87 with a 95\% confidence interval ranging from -15.61 to -8.13 . In addition, to know the magnitude of the intervention's effect, the calculation of the effect size was conducted.

$$
\begin{aligned}
& \text { Eta squared }=\frac{t^{2}}{t^{2}+(N-1)} \\
& \text { Eta squared }=\frac{(-6.47)^{2}}{(-6.47)^{2}+32-1} \text { ta squared }(-6.47)^{\wedge} 2 /(-6.47)^{\wedge} 2+32-1 \\
& \text { Eta squared }=\frac{41.87}{41.87+32-1} \\
& \text { Eta squared }=.57
\end{aligned}
$$

The guidelines (proposed by Cohen 1988) for interpreting this value are: .01=small effect, $.06=$ moderate effect, .14=large effect. Given our eta squared value of .57 we can conclude that there was a large effect, with a substantial difference in the students' writing scores obtained before and after the intervention.

Based on the result, in case of comparing the the impact of Process Based Approach to the students achievement, the study found out that the students' score in the postest was higher than the students' score in the pretest. On the other words, it showed more improvements in terms of content, organization, mechanics, and the overall results. Based on the paired t-test analysis, There was a statistically significant increase in writing score scores from Pretest $(M=68.59, S D=12.90)$ to Postest ( $M$ $=80.46, \mathrm{SD}=8.29), \mathrm{t}(31)=6.47, \mathrm{p}<.0005$ (two-tailed). The mean increase in Process Based Approach scores was 11.87 with a $95 \%$ confidence interval ranging from -15.61 to -8.13 . It was also supported with the result effect size (0.57) 57 which conclude that there was a large effect, with a substantial difference in the students' writing scores obtained before and after the intervention. It can be said, the use Process Based Approach is effective to teach writing to the students, especially in Junior High School.

Process approach needs to be commended here for it is indeed a very beneficial feature of the approach. The sequences of the activities in the Process Based Approach in this study needed a lot of students' hardwork in an effort to make writing a more positive and effective experience. This study also reveals that every step in Process Based Approach is very helpful in making the students' writing better 
trough each step provided. The majority of the students who had participated in this study liked the Process Based Approach because they found it positive, motivating and creating a collaborative atmosphere. Hence, every writing class should make use of the Process Based Approach especially for the Junior High School, because it is found effective. Not only for Junior High School, every academic writing class should do the same because it is found successful (Ozonawa, 2010).

\section{Conclusion}

Process Based Approach has been implemented by the researcher in SMP N 1 Singaraja especially in VII A7 class. The Process Based Approach has changed the way the teacher teaching writing to the students. In this case, there were five phases conducted by the teacher during teaching the students. These five phases were including prewriting, drafting, revising, editing, and editing. In the term of the impact of Process Based Approach toward students' achivement, the implementation of Process Based Approach in writing has given a positive impact towards the students' achievement. It was supported by the result of descriptive statistics analysis and inferential statistics analysis.

Based on the research findings and conclusion above, the researcher would like to propose some suggestions for other researchers. This study still needs more improvements to reach its goal. Therefore, it is suggested for further research to conduct and develop this research by expanding the research problem for those are interested in process based approach especially in writing. Beside, it is recommended that the school should maintain the implementation process based approach because it was found effective in improving students' writing achievement.

\section{References}

Abu- Jaleel, A. 2001. An Investigation of the Strategies of Teaching Writing for Ninth and Tenth Graders in Irbid Schools. Unpublished M.A Thesis. The University of Jordan, Amman.

Banat, S. 2007. The Effect of a Program Based on the Process Approach and Learning Style on Developing EFL Writing Skills Among Jordanian Secondary Stage Students. Unpublished Ph.D Thesis. Amman Arab University for Graduate Studies. Amman. Jordan.

Fathman, A. K. \& Whalley, E. 1990.Teacher response to student writing: focus on form versus content. In B. Kroll (Ed.), Second Language Writing (pp. 178-190). Cambridge: Cambridge University Press.

Fraenkel, J. R. \& Wallen, N. E.2003. How to design and evaluate research in education. Fifth ed. New York: McGraw-Hill.

Lindsay, P. 2000. Teaching English Worldwide, A new Practical Guide to Teaching English, 5(1). 179180.Burlingame,CA:Alta Book Center Publisher.

Pasand, P. G., \& Haghi, E. B. 201). Process-Product Approach to Writing: the Effect of Model Essays on EFL Learners' Writing Accuracy. International Journal of Applied Linguistics \& English Literature, 2(1), 75-79.

Sakoda, N., 2014. The distinction between process based and product based approaches to teaching writing and its effects on classroom methodology. Hiroshima University of Economics, 1141-1156. Retrieved from http://harp.lib.hiroshima-u.ac.jphuemetadata480.

Saputra, H., \& Marzulina, L. 2015. Teaching writing by using process genre approach to the eighth grade students of SMP Negeri 22 Palembang. Edukasi: Jurnal Pendidikan dan Pengajaran, 2 (1), 1-12. http://jurnal.radenfatah.ac.id/index.php/edukasi/article/view/592 